\title{
Fiancées and widows: women's encounters with death in the silent films of Fritz Lang
}

\author{
TOMASZ KŁYS \\ School of Media and Audiovisual Culture \\ Institute of Contemporary Culture \\ University of Łódź
}

\begin{abstract}
Kłys Tomasz, Fiancées and widows: women's encounters with death in the silent films of Fritz Lang. "Images" vol. XXV, no. 34. Poznań 2019. Adam Mickiewicz University Press. Pp. 155-162. ISSN 1731-450X. DOI 10.14746/i.2019.34.10.

In the silent Weimar films of Fritz Lang, the heroines have sudden encounters with Death, conceived both as an allegorical figure and as an unexpected violent end of the life of their fiancé, husband or loved one. The nameless Maiden, the main heroine of Der müde Tod (The Weary Death, known in English-language countries as Destiny, 1921), while looking for her fiancé, who was kidnapped by Death, tries three times to regain his life and finally, overcome by Death, commits suicide. Two queens of Burgundy in Die Nibelungen (The Nibelungs, 1924), Kriemhild and Brunhild, motivated by resentment and vengeance, as well as by unfulfilled love, finally appear to be zombie-like self-destructive monsters, destroying the social and political order, and the lives of many human beings. The paper, with the use of the psychoanalytic concepts of melancholy and the mourning "not-worked-out" by the persons who have lost their loved ones, analyses the ambiguous attitudes and self-destructive acts of these "women in black"..
\end{abstract}

KeYworDs: Death \& the Maiden, psychoanalysis, melancholy, Fritz Lang, Weimar cinema

In silent Weimar Films of Fritz Lang, their heroines have on their way sudden encounters with Death, conceived both as an allegorical figure and as unexpected violent end of the life of their fiancé, husband or loved one. The Nameless Maiden, the main heroine of Der müde Tod (The Weary Death, known in English-language countries as Destiny, 1921), while looking for her fiancé, kidnapped by Death, attempts three times to regain his life and finally, overcome by Death, commits suicide. Two queens of Burgundy in Die Nibelungen (The Nibelungs, 1924), Kriemhild and Brunhild, motivated by resentment and vengeance, as well as by unfulfilled love, finally appear as zombie-like self-destructive monsters, destroying the social and political order, and the lives of many human beings. The space trip of Friede, heroine of Frau im Mond (Woman in the Moon, 1929), with an unsuitable fiancé and the man who is really her beloved, finally appears to be a journey to the gates of death, a suicidal death that has the false appearance of Christian sacrifice and of being motivated by love.

The text, with its use of the psychoanalytic concepts of melancholy and mourning "notworked-out" by the persons who lost their loved ones, analyses the ambiguous attitudes and self-destructive acts of three of these four "women in black" (Maiden, Kriemhild, Brunhild). The context of these gloomy narratives is post-war trauma in 1920 s defeated Germany and the personal experience of Lang, whose mother and first wife died suddenly just before making of Der müde Tod. I do not intend to discuss it now, but am simply referring to the book Od Mabusego do Goebbelsa.[1]

Sigmund Freud in his famous article Mourning and Melancholia (Trauer und Melancholie)

[1] T. Kłys, Od Mabusego do Goebbelsa: Weimarskie filmy Fritza Langa i kino niemieckie do roku 1945, Łódź 2013, pp. 168-172, 190, 252-255, 271-272. 
describes "the work of mourning" (Trauerarbeit) in the following way:

Now in what consists the work which mourning performs? [...] The testing of reality, having shown that the loved object no longer exists, requires forthwith that all the libido shall be withdrawn from its attachments to this object. Against this demand struggle of course arises - it may be universally observed that man never willingly abandons a libido-position, not even when a substitute is already beckoning to him. The struggle can be so intense that a turning away from reality ensue, the object being clung to through the medium of a hallucinatory wish-psychosis. The normal outcome is that deference for reality gains the day. Nevertheless its behest cannot be at once obeyed. The task is now carried through bit by bit, under great expense of time and cathectic energy, while all the time the existence of the lost object is continued in the mind. Each single one of the memories and hopes which bound the libido to the object is brought up and hyper-cathected, and the detachment of the libido from it accomplished. Why this process of carrying out the behest of reality bit by bit, which is in the nature of a compromise, should be so extraordinarily painful is not at all easy to explain in terms of mental economics. It is worth noting that this pain (Schmerzunlust) seems natural to us. The fact is, however, that when the work of mourning is completed the ego becomes free and uninhibited again.[2]

It seems that the heroine of the framework story in Der müde Tod did not do effectively similar work, and what is more, the failure of her Trauerarbeit pushed her into the state known in psychiatry as depression, and named by Freud, according to a very long tradition, as melancholia. I am following here the interpretation of Tom Gunning in his book The Films of Fritz Lang: Allegories of Vision and Modernity. Gunning notices that for Freud, mourning falls into melancholy when the mourner has ambivalent emotions, and a certain psychological

[2] S. Freud, Mourning and melancholia, trans. J. Riviere, [in:] S. Freud, Collected Papers, vol.

IV, London 1925, p. 154.

[3] T. Gunning, The Films of Fritz Lang: Allegories of Vision and Modernity, London 200o, p. 27-28.

[4] Ovid, Metamorphoses, Book X, verses 27-68, trans. J. Dryden, [in:] Ovid's "Metamorphoses", London 1826, p. 246-247. conflict regarding his or her lost person. [3] The symptom of certain ambivalence of the Maiden towards the Boy is the fact that having recognized in the gloomy man the emblems of Death (thus having a "bad premonition") she left her Beloved One with the Stranger at the table in the inn from which he was kidnapped during her absence: a woman truly loving and caring (about her beloved), and not just afraid (for herself) would have not behaved in such a way.

The mythical personification of inconsolable mourning, finding its expression in melancholic poetry, is Orpheus. In classical literature, two works artistically described his despair after death of his beloved wife, Eurydice: Ovid's $\mathrm{Me}$ tamorphoses (Book X, 1-86; Book XI, 1-84) and Virgil's Georgics (Book IV, 455-509). Orpheus' speech to the gods of the Underworld, whom he begs with his poetic complaints to return to him his Eurydice, is almost exemplary in demonstrating the widower fallen in melancholy, who did not do his Trauerarbeit and is ready to commit suicide, or even has already attempted to end his own life (probably, in the figurative way of his "going down to Hell").

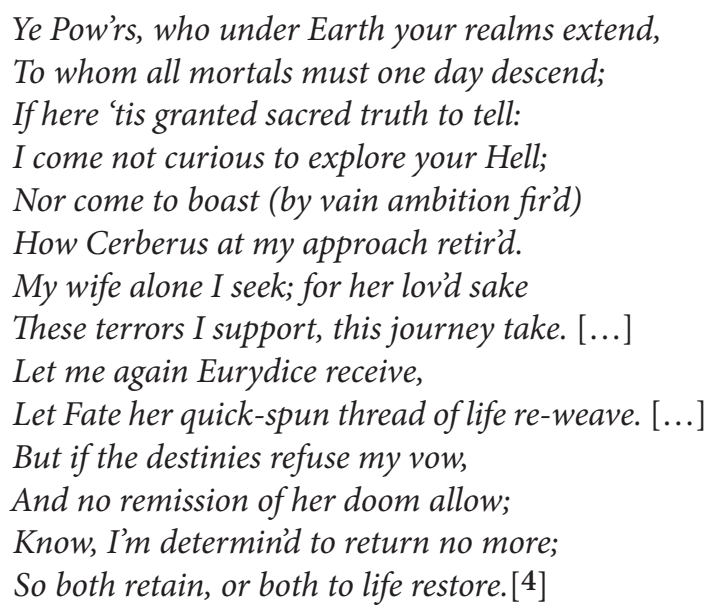

The last words of his speech to the gods of Hades very much resemble the words spoken to Death by the Maiden in Lang's film: "I could not vanquish you at that price. Now take my life also, for without my beloved it means less than nothing to me!"

The frame story's resemblance in Lang's film to the Ovid's version of the Orpheus myth 
consists of the fact of mourner's descent into the realm of death (i.e, frustrated suicidal attempt), the chance given by the ruler of this realm (unfulfilled) and the short, gloomy life after this "descent into hell", which at last finds its desired end. This end, both in the Ovid's poem and in Lang's film, takes place in violent, apocalyptic circumstances: Orpheus is torn to pieces by raging maenads, and the Maiden is killed in the fire; however, she is not "sacrificing her life for the life of a child" (as the crowd outside the burning house and the inattentive spectators of the film believe), but is very consciously comitting suicide.

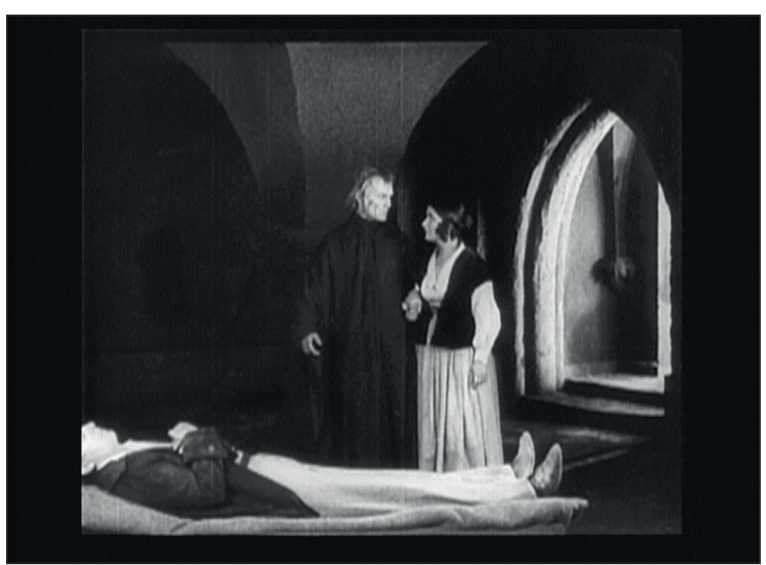

Fig. 1. Der müde Tod. Maiden married to her fiancé by Death

The final picture of Der müde Tod, the Maiden and her Beloved married by Death, irresistibly evokes end of the Orpheus story in Metamorphoses:

His ghost flies downward to the Stygian shore,

And knows the places it had seen before:

Among the shadows of the pious train

He finds Eurydice, and loves again;

With pleasure views the beauteous phantom's charms, And clasps her in his unsubstantial arms.

There side by side they unmolested walk,

Or pass their blissful hours in pleasing talk;

Aft or before the bard securely goes,

And, without danger, can review his spouse. [5]

The stories of Orpheus, an artist who was not saved from melancholic depression after his wife's loss, even by his art; and that of the Maiden in Lang's film, whose mourning after her beloved fell into suicidal melancholy, is clearly summarized in the following passage from Antoni Kępiński’s book Melancholia, regarding the questiom of "lost love":

A human being who lost the object of her or his love, or was never able to possess it, is, as a rule, a very sad person ('someone who does not love, sticks in death'); artistic creativity could not help her or him. This is because emotional attitudes ('towards' and 'from') are more important than creative attitude ('over') for their impact on the level of self-feeling (mood). Very often with the loss of the object of love, life also loses its sense, and becomes gray and empty. Such disconnection of the emotional link with that which gives life its colours could be the reason for comitting suicide.[6]

Lang's film's narration, which by various textual cues (or rather, by deceptive allusions creating a semantically indefinite "aura") suggests a "Christian meaning" in the Maiden's final deed and her previous feverish search for the Boy seems ideologically dangerous. The details of the heroine empty place at the inn's table, her questioning notables at the other table about her beloved, running into the town's market and asking a beggar about her Liebster, and walking in the moonlight when the herald announces the midnight hour - all of these details by resemblance of the events and the aura refer to the fragment of The Song of Songs (3,1-4) when the Beloved is searching for her Lover:

On my bed at night I sought

the man who is my sweetheart:

I sought but could not find him!

So I shall get up and go through the city;

in the streets and in the squares,

I shall seek my sweetheart.

I sought but could not find him!

I came upon the watchmen -

Those who go on their rounds in the city:

"Have you seen my sweetheart?"

[5] Ovid, Metamorphoses, Book XI, verses 94-103, trans. J. Dryden, [in:] Ovid's “Metamorphoses"..., p. 277.

[6] A. Kępiński, Melancholia, Warszawa 1974, p. 51. 
Barely had I passed them

when I found my sweetheart!

I caught him, would not let him go [...][7]

The Maiden in Lang's film also soon finds her beloved, albeit only as a phantom in the procession of the dead, penetrating the boundless wall of Death's realm. And although contrary to the biblical heroine she could not "catch" her beloved, she "does not let him go" in the sense that she will so stubbornly refuse separation from him that it will end with her suicide. Finding similarities between the night wandering of the Maiden and the quoted passages of the biblical poem is not overinterpretation. It is also suggested by the following sequence, when the Maiden reaches out for the bottle of poison, inspired by the verse from The Song of Songs $(8,6)$, taken out of context: Love is strong as death. What is more, this poison (which is not certain, but is suggested by the alluding details in the narration) is mandrake, a plant also mentioned by its positive aspects in The Song of Songs $(7,14)$. However, the stylization of film's pair separation for the separation of Beloved and her Lover from The Song of Songs, poem, in which love has not pathological but theological dimension, is simply abuse, usurpation of a sense inadequate in given context.

Interpreting the final deed of the Maiden as "suicide after mourning not 'worked out' and transformed therefore into melancholy" gives much greater coherence to the narrative events than the final sentence: "Who gives his life away, shall gain it" (it is not clear who is speaking these words: Death? The impersonal narrator of the film?) This sentence is suggestive of the Maiden's "sacrifice", which she herself also stressed earlier, telling Death: "I could not vanquish you at that price. Now take my life also, for without my beloved it means less than nothing to me!" This "also" means, at prima facie "not on only my Beloved but also me myself" but in context, after reflection, sounds more like

[7] The Song of Songs, 3, 1-4, [in:] The New Jerusalem Bible, New York 1998, p. 1033. "instead". However, instead of whom? Death did not demand the life of this particular child; it was the Maiden's idea to fulfil with the child's life Death's condition to "deliver" to him someone's unfinished life before midnight as a price for returning her beloved to life. Therefore, the heroine does not have to pay Death with her own life for saving the child and returning him to his mother (regardless, together with the extinguishing action, this is one of only two of the Maiden's deeds really worthy of praise and returning her for a while to the principle of reality). And if her life would really have been a "ransom" to Death for her beloved's life - true love, Christian or Christian-like caritas would certainly allow for it - then Death would take her life, restoring life to the Boy. As happens in Euripides' tragedy Alkestis, in which the title heroine gives her own life to the gods of underworld in exchange for her husband Admetos, who returned to life instead of Alkestis.

The myth of Alkestis is, in Lang's film, evoked by the triple refusal of other persons (apothecary, beggar, old woman in the almshouse) to give their lives "instead" (instead of Maiden's beloved), although each of their lives is near its end, since these persons are old and "without future". Similarly, in Euripides' tragedy, the elderly parents of Admetos refused to sacrifice the short duration of their lives for the life of their young son. However, Alkestis, who does not regain her husband but unselfishly and magnanimously dies instead and for him, truly could be regarded as the personification of before-Christian caritas. In Lang's film, the Maiden, by her words, in fact usurps herself of the analogy of her suicide to the heroic sacrifices of Euripides' heroine, and narration once again facilitates this usurpation by "aura" created unclearly by scattered detailes, incoherent with the main line of action - despite the fact that some moments earlier Maiden appeared as the "emissary of Death" from whom the old people run away in panic (such sudden escape was, after all, the immediate cause of the fire). Melancholy, resulting from mourning "not 
worked out", can not only turn into a suicidal drive, but also into aggression against other people, which is allegorically represented by the Maiden's insistent requests for the lives of others, and in Lang's other films - first of all by the vengeful lust of another widow, Kriemhild in Die Nibelungen. Disguised as "being-to-love", the Maiden's actions are in fact "being-to-death", and even, which is demonstrated by the final sequence in the narrative frame - "for-death".

One of the central figures of Fritz Lang's two-part epic Die Nibelungen (and certainly dominant in its second part, Kriemhild's Rache Kriemhild's Revenge) is Kriemhild, at first fiancé, then wife, and finally widow of the murdered hero, Siegfried, king of Niederlanden. Her story is condensed in the first book (the so-called "First Adventure") of Das Nibelungenlied, the heroic narrative poem which is the basis for Fritz Lang's adaptation.

There once grew up in Burgundy/ a maid of noble birth,

Nor might there be a fairer/ than she in all the earth: Kriemhild hight the maiden, / and grew a dame full fair,

Through whom high thanes a many/ to lose their lives soon doomed were.

'Twould well become the highest/ to love the winsome maid,

Keen knights did long to win her,/ and none but homage paid.

Beauty without measure, / that in sooth had she, And virtues wherewith many/ ladies else adorned might be.

Three noble lords did guard her,/ great as well in might,

Gunther and Gernot,/ each one a worthy knight, And Giselher their brother,/ a hero young and rare. The lady was their sister/ and lived beneath the princes' care.
These lords were free in giving,/ and born of high degree;

Undaunted was the valor/ of all the chosen three.

It was the land of Burgundy/ o'er which they did command,

And mighty deeds of wonder/ they wrought anon in Etzel's land.

At Worms amid their warriors/ they dwelt, the Rhine beside,

And in their lands did serve them/ knights of mickle pride,

Who till their days were ended/ maintained them high in state.

They later sadly perished/ beneath two noble women's hate. $[\ldots]$

Amid this life so noble/ did dream the fair Kriemhild How that she reared a falcon,/ in beauty strong and wild,

That by two eagles perished; the cruel sight to see Did fill her heart with sorrow/ as great as in this world might be.

The dream then to her mother/ Queen Ute she told, But she could not the vision/ than thus more clear unfold:

"The falcon that thou rearedst,/ doth mean a noble spouse:

God guard him well from evil/ or thou thy hero soon must lose." [...]

Long time, too, did Kriemhild/ her heart from love hold free,

And many a day the maiden/ lived right happily,

Ere good knight saw she any/ whom she would wish to woo.

In honor yet she wedded/ anon a worthy knight and true.

He was that same falcon/ she saw the dream within Unfolded by her mother./ Upon her nearest kin, That they did slay him later,/ how wreaked she vengeance wild!

Through death of this one hero/ died many another mother's child. [8]

[8] The Song of the Nibelungs, First Adventure "Kriemhild's Dream", [in:] The Nibelungenlied, trans. G.H. Needler, New York 1904, pp. 1-6. 


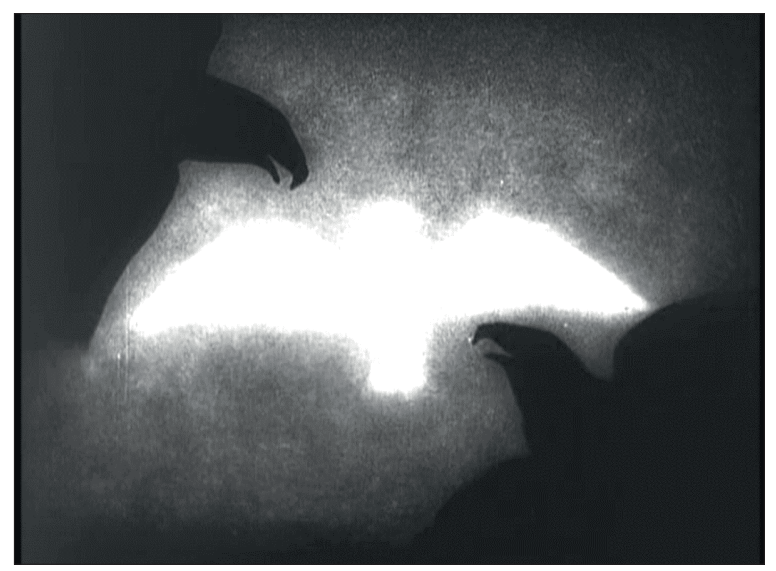

Fig. 2. Die Nibelungen. White falcon from Kriemhild's dream killed by two black eagles

The central episode of Das Nibelungenlied and Fritz Lang's adaptation is the quarrel of two Burgund queens, Brunhild and Kriemhild, on the steps of a cathedral in Worms, capital of the Burgunds' kingdom. For Brunhild, who lost her kingdom in Iceland, inhabited only by females and resembling the world of Juliusz Machulski's Seksmisja, and, what is worse, was defeated in an inexplicable way by the weakling and coward, Gunter, who by that victory gained the legal right to marry her, the only compensation is the position of the sovereign's wife, the queen of Burgundy. Therefore, she reacts nervously when she is informed that Kriemhild, her sister-in-law, is to become the wife of a vassal (she was mislead by Siegfried's self-presentation in Iceland as Gunter's vassal and does not know that Siegfried is, in fact, also a king, of the neighbouring kingdom of Niederlanden). When Kriemhild becomes Siegfried's wife (which is worse, at the same time and before the same altar as Brunhild herself becomes Gunter's wife during a truly "royal mass"), and what is more, when Siegfried six months later brings into Worms the fabulous treasure of Nibelungen, Brunhild is threatened in her superior status and demands from her weak husband the "removing" of his brotherin-law from the country. However, this is impossible, since Siegfried is the sovereign ruler of the neighbouring kingdom. Therefore, in her desperation, Brunhild plans to humiliate her royal sister-in-law: dressed in the regalia of the queen of Burgundy, she demands from Kriemhild precedence during their way to the mass in the cathedral. Of course, for proud Kriemhild, both queen of another country and sister of the king of Burgundy, such a demand is totally unacceptable. In this famous scene of two queens' quarrel before the Worms cathedral, equally important element are hubris, the sense of self-importance and the lust for power, and erotic jealousy, the desire for the same object of love; if it is not possible to possess it, it is even better to destroy it than to allow it to be owned by someone else (mimetic desire, so called by René Girard, treats "beloved" persons as objects, in terms of possession). Brunhild who, with truly feminine intuition recognizes in Siegfried the only worthy human being, as a man and as a rival in the sport of struggle, cannot accept his happiness with Kriemhild; by humiliating her sister-in-law at the cathedral steps, she takes her revenge on both of them. On the other hand, if Kriemhild loved Siegfried unconditionally, with no ambivalence and restrictions, she would not disclose Brunhild's scandalous bracelet, which was the ambiguous "proof" of Brunhild's virginity being taken not by her weak husband Gunter, but in fact by Siegfried. Betraying her husband's confidence, she semi-consciously compensated in this way for her jealousy being aroused by Siegfried's "helping" Gunter to "break Brunhild's resistance", in addition to publicly humiliating the queen (from the second part of the film, we know that for the taste of revenge and execution from others what they "owe" her, she is ready to sacrifice everything and everybody, including her child and brothers). After all, is not the symptom of similar ambivalence - the unconscious will to punish Siegfried - definitely zealously pointing out to Hagen the unprotected place on Siegfried's body, where fell the linden leaf?

If, for the Huns' king Etzel, marriage with Siegfried's widow, the owner of the Nibelungen treasure and sister of Burgundy's ruler, has the obvious political dimension of conquest à la 
felix Austria, for Kriemhild, it creates simply an opportunity for vengeance that should be easier and more accesssible for her as the wife of perhaps the most powerful king of the era than for a poor widow-resident in the court of her brother, in permanent proximity to the hateful Hagen. After all, Hagen perfectly understands the danger of her marriage to the king of the Huns (similar to the previous one with Siegfried): in the early Middle Ages, the wife's loyalty to her husband's house stood in conflict with the loyalty to her own tribe, clan or family. Both kinds of Treue (loyalty, fidelity), in the case of such dramas as the Kriemhild tragedy, in situations of refusal or the not-yet-accomplished internalization of Christianity, then very superficial, apperared irreconciliable.

Perhaps the most terrible aspect of mimetic violence is the rule "an eye for an eye" (or "blood calls for blood", as it is twice said to Rüdiger by Hildebrand and Kriemhild). Kriemhild executing the justice "owing to" her leads to unleashing, on an apocalyptic scale, a great mimetic crisis in which revenging the "widow's wrong" causes the destruction of the royal dynasty and perhaps the whole state of Burgundy. But for Kriemhild, "legal justness" overlaps with the psychic crisis connected to the mourning "not worked out" after Siegfried's death; symptoms of her inability to accept her separation from her dead husband (such acceptance is a condition for normal existence in society) are her incessant sitting in the chapel close to Siegfried's corpse before the funeral and in the tomb crypt afterwards, pilgrimage to the spring where he was killed, and carefully keeping the bundle with the "holy" soil soaked with Siegfried's blood until it could also be satiated with the blood of his killer, Hagen, personally killed by Kriemhild herself. Perhaps by presenting her widow's mourning so ostentatiously, Kriemhild suppresses her own guilty conscience; it was due to her own double indiscretion (presenting Brunhild's scandalous bracelet, pointing out to Hagen the place of the linden leaf) that Siegfried found himself in deadly danger. In the second part of the film, Kriemhild behaves like a zombie, walking very stiffly, staring somewhere into the distance with a gaze that does not see her interlocutor. Her metamorphosis is stressed by the change of her white robe from her maidenhood and marriage periods to the dark clothes of a widow. Kriemhild, in her widow's melancholy, which transforms into agression directed not only at Siegfried's murderer but also to every person she meets, somehow resembles the Maiden from Der müde Tod, who requested the lives of other people for the life of her beloved. However, in the case of the heroine of the previous film, it was only a short phase (perhaps because everything happened in one night), and in the case of Kriemhild, it is a prolonged, terrifyingly permanent state. In her persistent pursuit of justice, Kriemhild forgets blood kinship: with practically no regret, she witnesses the deaths of her brothers, Giselher and Gernot, and personally gives the order to behead Gunter, her brother who betrayed her husband. The most gloomy trait of her personality is, however, her lack of motherly love to her own child; and what is worse, by bringing her son to the feral banquet, she rather consciously exposes him to death. Provoking Hagen to infanticide (Hagen, surprisingly willingly, as if precipitating destiny, takes this dark game with her), she reaches her aim, which is involvement of king Etzel in her revenge.

Etzel, despite his infamy and wild look, seems to be a person with strong sense of morality. Only Etzel, not Kriemhild, who is possesed with revenge and incessantly recollects dead Siegfried, shows parental love to their own son. Only Etzel himself definitely opposes all plots and traps against the Burgundian guests because the law of hospitality is holy for him. His morality is, however, unchristian and tribal, and according to this morality, it is impossible to forgive someone a great sin, like infanticide. In such a case, only terrible punishment and vengeance is possible. Kriemhild, by the infanticide provoked by herself and comitted by Hagen, reaches her aim, and after death of their child, Etzel has only one aim, the same as Kriemhild's: to kill Hagen Tronje, even if hun- 
dreds of other people have to die in the process. Etzel, like Kriemhild, is not able to "work out" his mourning: after his son's death, he stares at everybody with an insane, unseeing gaze, incessantly rocking his child's corpse.

Similarly, the principle "an eye for an eye" rules over Brunhild's deeds. The Queen of Burgundy takes revenge on Siegfried for defeating her in the arena, for rejecting her as a woman, for the loss of her kingdom of Iceland, for taking her virginity (and, what is worse, doing so in the name and appearance of the weak and cowardly Gunter), for destroying her Valkirian power, and for her public humiliation by her hateful rival, her royal sister-in-law. Brunhild initiates the plot with Gunter and Hagen to kill Siegfried, demanding his death as compensation for all her loses and defamation. But in reaching her aim - the death of Siegfried - Brunhilds loses the game. Having destroyed the object of her only and true love, she does not see sense to live any longer. Not being able - like Kriemhild, like Etzel - to do the necessary Trauerarbeit, she falls into depresion and commits seppuku-like suicide before Siegfried's corpse in the chapel. Another reason for this suicide could be the feeling of guilt. Brunhild's death is the invention of Thea von Harbou and Lang's screenplay: in the literary epic, Brunhild still lives as Gunter's wife in the court of Worms, but mentions of her are less and less numerous. She definitely stops fulfilling any active role in the narrative, as if she vanishes into the darkness of history. In some sense, the film's screenplay chose a solution that is more logical and better motivated, both symbolically and psychologically. Her departure from the world, together with Siegfried, means the definite vanishing of the world of myth, legend and wonder, and simultaneously, the inevitable defeat of the pagan ethos which elevated both destructive mimetic desire and mimetic violence as love, heroism and power. After the deaths of both Siegfried and Brunhild, in the second part of film, we shall no more be seduced by the "feeric", "magic" aura of Nordic legends; myth will withdraw itself in order to give place to history, and naked violence, totally devoid of mythological embellishments, will show itself in its whole hideousness and monstrosity.

Mourning could not last too long, beyond the culturally-defined and socially-accepted time. If it is "not-worked-out" (in the Freudian sense) by the mourner, it is always destructive, either to the mourner her- or himself, or to other persons from mourner's milieu. Not-workedout mourning, commonly known in culture as melancholia (melancholy), transforms itself into a suicidal drive, leading to the mourner's self-provoked death, as the cases of the Maiden and Brunhild demonstrate. What is more socially dangerous, the sense of emptiness after a beloved person's death, could also lead to aggression directed against other people. This aggression could simply be treated as revenge, but usually is treated by the mourner as a "call for justice" (case of Kriemhild). More complex is attitude of the Maiden, who demands the life of another person "instead" of her beloved. Unable to kill the infant as the price for her beloved one's life, she finally chooses suicide. At the end of the way followed by the "permanent mourners", Death always stands.

\section{B I B L I O G R A P H Y}

Freud S., Mourning and melancholia, transl. J. Riviere, [in:] S. Freud, Collected Papers, vol. IV, London 1925, pp. $152-170$

Gunning T., The Films of Fritz Lang: Allegories of Vision and Modernity, London 2000

Kępiński A., Melancholia, Warszawa 1974

Kłys T., Od Mabusego do Goebbelsa: Weimarskie filmy Fritza Langa i kino niemieckie do roku 1945, Łódź 2013

Ovid, Ovid's Metamorphoses, London 1826

The New Jerusalem Bible, New York 1990

The Nibelungenlied, trans. G. Henry Needler, New York 1904 